\title{
FAKTOR-FAKTOR YANG BERHUBUNGAN DENGAN STUNTING PADA BALITA USIA 24-59 BULAN DI DESA BERASANG KECAMATAN KISAM TINGGI KABUPATEN OKU SELATAN TAHUN 2020
}

\author{
U'Un Sintia ${ }^{1}$, Faulia Mauluddina ${ }^{2}$ \\ Program Studi DIII Kebidanan STIKES Mitra Adiguna Palembang. \\ Komplek Kenten Permai Blok J No 9-12 Bukit Sangkal Palembang 30114 \\ Email : faulia.mauluddina@gmail.com
}

\begin{abstract}
Abstrak
Indonesia menduduki pringkat kelima dunia untuk jumlah anak dengan kondisi stunting. Menurut Riskesdas tahun 2013, menunjukan prevalensi balita stunting di Indonesia mencapai 37\% (terdiri dari $18 \%$ sangat pendek dan 19,2\% pendek) yang berarti mengalami peningkatan tahun 2010 (35.6\%) dan tahun 2007 (36,8\%). Tujuan penelitian ini adalah untuk mengetahui faktor-faktor yang berhubungan dengan stunting pada balita usia 24-59 bulan Desa Berasang Kecamatan Kisam Tinggi Kabupaten OKU Selatan tahun 2020. Metode penelitian yang digunakan adalah metode analitik dengan pendekatan cross sectional. Hasil penelitian uji statistik didapatkan ada hubungan yang bermakna antara tinggi badan ibu ( $p$ value $=0,026$ ), riwayat ASI eksklusif ( $p$ value $=0,001$ ) dan tidak ada hubungan bermakna antara riwayat BBLR ( $p$ value =0,983) dengan stunting pada balita usia 24-59 bulan di Desa Berasang Kecamatan Kisam Tinggi Kabupaten Oku Selatan tahun 2020. Saran diharapkan tenaga kesehatan khususnya bidan yang ada di Desa Berasang Kecamatan Kisam Tinggi Kabupaten OKU Selatan agar lebih meningkatkan dalam pemberian informasi kepada masyarakat melalui pendekatan persuasif dengan menjelaskan kepada masyarakat bahwa stunting harus atau dapat dicegah mulai dari memenuhi gizi ibu hamil, gizi bayi baru lahir dan 1000 hari pertama kehidupan.
\end{abstract}

Kata Kunci : Stunting, Tinggi Badan Ibu, Riwayat ASI Eksklusif, Riwayat BBLR

\begin{abstract}
Indonesia occupied the fifth pringkat world for the number of children with stunting condition. According to Riskesdas 2013, it shows that the prevalence of stunting under five in Indonesia reaches $37 \%$ (consisting of $18 \%$ very short and 19.2\% short) which means that it has increased in 2010 (35.6\%) and 2007 (36.8\%). The purpose of this research was to determine the factors related to stunting in children aged 24-59 months in Berasang Village, Kisam Tinggi District, OKU Selatan Regency in 2020. The research method used is analytical method with cross sectional approach. The results of the statistical test showed that there was a significant relationship between maternal height ( $p$ value = $0.026)$, a history of exclusive breastfeeding $(p$ value $=0.001)$ and there was no significant relationship between a history of LBW ( $p$ value $=0.983)$ and stunting in children aged 24-59 months in Berasang Village, Kisam Tinggi District, Oku Selatan Regency in 2020. Suggestions are expected that health workers, especially midwives in Berasang Village, Kisam Tinggi District, OKU Selatan Regency, to further improve in providing information to the community through a persuasive approach by explaining to the community that stunting must or can be prevented starting from fulfilling the nutrition of pregnant women, nutrition of newborns and the first 1000 days of life.
\end{abstract}

Keywords: Stunting, Maternal Height, Exclusive Breastfeeding History, BBLR History 


\section{PENDAHULUAN}

Gizi kurang merupakan salah satu masalah gizi yang banyak terjadi pada balita di dunia. Data UNICEF tahun 2018 menunjukkan bahwa hampir separuh dari semua kematian pada anak-anak di bawah 5 tahun disebabkan oleh kekurangan gizi, yang menyebabkan 3 juta jiwa anak meninggal per tahun. Permasalah gizi kurang meliputi wasting dan stunting, sedangkan overweight merupakan aspek lain dari malnutrisi. Pada tahun 2016, 52 juta balita atau $7,7 \%$ mengalami wasting dan $22,9 \%$ atau satu dari empat anak dibawah usia 5 tahun diseluruh dunia mengalami pertumbuhan yang terhambat (Unicef dalam Dwi, 2018).

Indonesia menduduki pringkat kelima dunia untuk jumlah anak dengan kondisi stunting. Menurut Riskesdas tahun 2013, menunjukan prevalensi balita stunting di Indonesia mencapai 37\% (terdiri dari 18\% sangat pendek dan $19,2 \%$ pendek) yang berarti mengalami peningkatan tahun 2010 (35.6\%) dan tahun 2007 (36,8\%). Hampir 9 juta balita di Indonesia termasuk kategori stunting. Prevalensi balita stunting menjadi masalah kesehatan masyarakat jika prevalensinya 20\% atau lebih (Riset kesehatan dasar dalam Dewi, 2019).

Prevalensi balita menjadi pendek merupakan masalah kesehatan masyarakat jika prevalensinya $20 \%$ atau lebih. Prevalensi balita pendek di Indonesia masih sangat tinggi dan merupakan masalah kesehatan yang harus di tanggulangi. Prevalensi balita pendek di Indonesia juga tinggi dibandingkan Myanmar (35\%), Vietnam (23\%), Malaysia (17\%), Thailand (16\%), dan singapura (4\%) (Kemenkes RI dalam Dwi, 2018).

Stunting atau pendek merupakan kondisi gagal tumbuh pada bayi (0-11 bulan) dan anak balita (12-59 bulan) akibat dari kekurangan gizi kronis terutama dalam 1000 hari pertama kehidupan sehingga anak terlalu pendek untuk usianya. Kekurangan gizi terjadi sejak bayi dalam kandungan dan pada masa awal stelah bayi baru lahir, tetapi kondisi stunting baru nampak setelah berusia 2 tahun. Balita dikatakan pendek jika nilai zscore-nya panjang badan menurut umur $(\mathrm{PB} / \mathrm{U})$ atau tinggi badan menurut umur (TB/U) kurang dari -2D/standar deviasi (stunted) dan kurang dari -3SD (severely stunted). Balita stunted akan memiliki tingkat kecerdasan tidak maksimal, menjadi lebih rentan terhadap penyakit dan masa depan dapat berisiko menurunnya tingkat produktivitas. Pada akhirnya, secara luas, stunting akan dapat menghambat pertumbuhan ekonomi dan meningkatkan kemiskinan (Ramayulis dkk, 2018).

Keadaan kurang gizi yang diukur berdasarkan indeks tinggi badan menurut umur (TB/U) dibandingkan dengan standar biasanya digunakan pada balita. Stunting atau yang disebut juga kurang gizi kronis, dimana terjadi pertumbuhan lineir pada anak. Bila skor-z TB/U dibawah -2.00 SD diklasifikasi kurang gizi akut, bila skor-z TB/U dibawah $\quad-3.00$ diklasifikasikan kurang gizi akut tingkat berat, bila skor-z TB/U diatas -2.00 diklasifikasikan normal (Sandjaja, Atmarita, 2009).

Stunting adalah masalah kurang gizi kronis yang disebabkan oleh asupan gizi yang kurang dalam waktu cukup lama akibat pemberian makanan yang tidak sesuai dengan kebutuhan gizi. Stunting terjadi mulai janin masih dalam kandungan dan baru nampak saat anak berusia dua tahun. Kekurangan gizi pada usia dini meningkatkan angka kematian bayi dan anak, menyebabkan penderitanya mudah sakit dan memiliki postur tubuh tak maksimal saat dewasa. Kemampuan kognitif para penderita juga berkurang, sehingga mengakibatkan kerugian ekonomi jangka panjang bagi Indonesia (Suhaimi, 2019). 
Stunting bukan hanya menjadi permasalahan gizi pada balita secara nasional, melainkan menjadi permasalahan global. Hal ini dibuktikan dengan jumlah anak mengalami stunting di negara berkembang yaitu 165 juta anak sekitar $80 \%$ negara berkembang menyumbang untuk kasus stunting (MCA-Indonesia, 2013). Masalah gizi khususnya stunting pada balita disebabkan asupan makan yang kurang memadai dan penyakit yang merupakan penyebab langsung masalah gizi pada anak. Keadaan tersebut terjadi karena praktek pemberian makan yang tidak tepat, penyakit infeksi yang berulang, perilaku kebersihan dan pengasuh yang buruk, penggunaan air yang tidak bersih, lingkungan yang tidak sehat, pendapatan yang rendah dan keterbatasan akses terhadap pangan (Unicef dalam Dewi, 2018).

Stunting yang dialami anak dapat disebabkan oleh tidak terpaparnya periode 1000 hari pertama kehidupan mendapat perhatian khusus karena menjadi penentu tingkat pertumbuhan fisik, kesadaran, dan produktivitas seseorang dimasa depan. Stunting dapat pula disebabkan tidak melewati periode emas yang dimulai 1000 hari pertama kehidupan yang merupakan pembentukan tumbuh kembang anak pada 1000 hari pertama. Pada masa tersebut nutrisi yang diterima bayi saat didalam kandungan dan menerima ASI memiliki dampak jangka panjang terhadap kehidupan saat dewasa. Hal ini dapat terlampau maka akan terhindar dari terjadinya stunting pada anak-anak dan status gizi yang kurang (Depkes, 2015).

Berdasarkan data yang didapat dari Puskesmas Kisam Tinggi, tahun 2019 jumlah balita yang mengalami stunting sebanyak 6 orang (Puskesmas Kisam Tinggi, 2019).

Berdasarkan latar belakang diatas, peneliti tertarik untuk melakukan penelitian dengan judul "Faktor-faktor yang berhubungan dengan stunting pada balita usia 24-59 bulan di Desa Berasang Kecamatan Kisam Tinggi Kabupaten Oku Selatan tahun 2020"

\section{METODE PENELITIAN \\ Jenis Penelitian}

Jenis penelitian ini kuantitatif menggunakan metode analitik dengan pendekatan cross sectional.

Waktu dan Tempat Penelitian

Penelitian ini dilaksanakan pada tanggal 16-20 April 2020 di Desa Berasang Kecamatan Kisam Tinggi Kabupaten Oku Selatan.

\section{Target/Subjek Penelitian}

Semua ibu dan balita usia 24-59 bulan di Desa Berasang Kecamatan Kisam Tinggi Kabupaten OKU Selatan.

\section{Prosedur}

1. Menjelaskan tujuan penelitian kepada responden (ibu balita).

2. Membuat Informed Consent dengan responden (ibu balita).

3. Melakukan penimbangan berat badan responden (balita) dan mengajukan lembar kuesioner kepada responden (ibu balita).

4. Memandu responden (ibu balita)dalam mengisi pertanyaan-pertanyaan yang ada pada lembar kuesioner.

5. Memeriksa kembali lembar kuesioner yang sudah diisi responden (ibu balita).

6. Mengucapkan terima kasih dan salam pada responden (ibu balita).

\section{Data, Instrumen, dan Teknik Pengumpulan Data}

Teknik pengumpulan data pada penelitian ini menggunakan kuesioner sebagai alat bantu dalam pengambilan data.

\section{Teknik Analisa Data}

\section{Analisa Univariat}

Analisa univariat dilakukan terhadap tiap variabel dari hasil penelitian yaitu variabel independen (tinggi badan ibu, riwayat ASI Eksklusif dan riwayat BBLR) dan variabel dependen (stunting) yang 
dianalisis dengan menggunakan tabel distribusi frekuensi.

\section{Analisa Bivariat}

Analisa bivariat adalah analisa data untuk mengetahui hubungan antara variabel independen dengan variabel dependen yang dianalisis dengan uji chisquare $\left(\mathrm{x}^{2}\right)$ dengan taraf signifikan $(\alpha)=$ 0,05 .

\section{HASIL PENELITIAN DAN PEMBAHASAN \\ Analisa Univariat}

Analisa ini dilakukan untuk mengetahui distribusi frekuensi dan persentase dari variabel independen (tinggi badan ibu, riwayat ASI Eksklusif dan riwayat BBLR) dan variabel dependen (stunting) data disajikan dalam bentuk tabel dan teks.

\section{Stunting}

Penelitian ini dilakukan pada 40 responden dimana stunting dikelompokkan menjadi 2 kategori yaitu Ya (Jika TB/U < -2 standar deviasi) dan Tidak (Jika TB/U $\geq-2$ standar deviasi). Adapun tabel distribusi frekuensi stunting adalah sebagai berikut :

Tabel 1 Distribusi Frekuensi Responden

Berdasarkan Stunting di Desa

Berasang Kecamatan Kisam Tinggi

Kabupaten Oku Selatan Tahun 2020

\begin{tabular}{clcc}
\hline No & Stunting & Frekuensi & Persentase \\
\hline 1. & Ya & 23 & 57,5 \\
2. & Tidak & 17 & 42,5 \\
\hline & Jumlah & $\mathbf{4 0}$ & $\mathbf{1 0 0}$ \\
\hline
\end{tabular}

Dari tabel 1 diatas dapat dilihat bahwa distribusi frekuensi sebagian besar responden mengalami stunting $(57,5 \%)$.

\section{Tinggi Badan Ibu}

Penelitian ini dilakukan pada 40 responden dimana timggi badan ibu dikelompokkan menjadi 2 kategori yaitu Beresiko (Jika tinggi badan $<150 \mathrm{~cm}$ ) dan tidak beresiko (Jika tinggi badan $\geq 150 \mathrm{~cm}$ ). Adapun tabel distribusi frekuensi tinggi badan ibu adalah sebagai berikut :

Tabel 2 Distribusi Frekuensi Responden Berdasarkan Tinggi Badan Ibu Di Desa Berasang Kecamatan Kisam Tinggi Kabupaten Oku Selatan Tahun 2020

\begin{tabular}{cccc}
\hline No & $\begin{array}{c}\text { Tinggi Badan } \\
\text { Ibu }\end{array}$ & Frekuensi & Persentase \\
\hline 1. & Beresiko & 15 & 37,5 \\
2. & Tidak beresiko & 25 & 62,5 \\
\hline & Jumlah & $\mathbf{4 0}$ & $\mathbf{1 0 0}$ \\
\hline
\end{tabular}

Dari tabel 2 diatas dapat dilihat bahwa distribusi frekuensi responden sebagian besar tidak beresiko $(62,5 \%)$.

\section{Riwayat ASI Eksklusif}

Penelitian ini dilakukan pada 40 responden dimana riwayat ASI Eksklusif dikelompokkan menjadi 2 kategori yaitu Tidak (Jika pemberian MPASI diberikan sebelum usia 6 bulan) Ya (Jika pemberian ASI saja sampai usia 6 bulan). Adapun tabel distribusi frekuensi riwayat ASI Eksklusif adalah sebagai berikut :

Tabel 3 Distribusi Frekuensi Responden Berdasarkan Riwayat ASI Eksklusif Di Desa Berasang Kecamatan Kisam Tinggi Kabupaten Oku Selatan Tahun 2020

\begin{tabular}{clcc}
\hline No & $\begin{array}{c}\text { Riwayat ASI } \\
\text { Eksklusif }\end{array}$ & Frekuensi & Persentase \\
\hline 1. & Tidak & 19 & 47,5 \\
2. & Ya & 21 & 52,5 \\
\hline & Jumlah & $\mathbf{4 0}$ & $\mathbf{1 0 0}$ \\
\hline
\end{tabular}

Dari tabel 3 diatas dapat dilihat bahwa distribusi frekuensi responden sebagian besar diberikan ASI Eksklusif (52,5\%).

\section{Riwayat BBLR}

Penelitian ini dilakukan pada 40 responden dimana Riwayat BBLR dikelompokkan menjadi 2 kategori yaitu Ya (Jika berat badan lahir < 2500 gram) dan Tidak (Jika berat badan lahir $\geq 2500$ gram). Adapun tabel distribusi frekuensi riwayat BBLR adalah sebagai berikut :

Tabel 4 Distribusi Frekuensi Responden

Berdasarkan Riwayat BBLR Di Desa Berasang Kecamatan Kisam Tinggi Kabupaten Oku Selatan Tahun 2020

\begin{tabular}{clcc}
\hline No & $\begin{array}{c}\text { Riwayat } \\
\text { BBLR }\end{array}$ & Frekuensi & Persentase \\
\hline 1. & Ya & 7 & 17,5 \\
2. & Tidak & 33 & 82,5 \\
\hline & Jumlah & $\mathbf{4 0}$ & $\mathbf{1 0 0}$ \\
\hline
\end{tabular}

Dari tabel 4 diatas dapat dilihat bahwa distribusi frekuensi responden sebagian besar tidak memiliki riwayat BBLR $(82,5 \%)$. 


\section{Analisa Bivariat}

Analisa ini dilakukan untuk mengetahui hubungan antara variabel independen (tinggi badan ibu, riwayat ASI Eksklusif dan riwayat BBLR) dan variabel dependen (stunting). Penelitian ini menggunakan uji statistik Chi Square. Menggunakan sistem komputerisasi Statistical Program for Social Science (SPSS) yang merupakan paket atau program statistik yang dibuat untuk mengolah atau menganalisa data. Batas kemaknaan pada $\alpha=0,05$. Jika $p$ value $\leq \alpha$ $=0,05$ artinya ada hubungan yang bermakna (signifikan) antara variabel independen dan variabel dependen, jika $p$ value $>\alpha=0,05$ artinya tidak ada hubungan yang bermakna (signifikan) antara variabel independen dan variabel dependen.

Hubungan Tinggi Badan Ibu Dengan Stunting pada Balita Usia 24-59 Bulan di Desa Berasang Kecamatan Kisam Tinggi Kabupaten Oku Selatan

Jumlah responden dalam penelitian ini adalah 40 orang. Analisis bivariat ini digunakan untuk mengetahui hubungan antara tinggi badan ibu dengan stunting yang dapat dilihat pada tabel dibawah ini.

Tabel 5 Hubungan Tinggi Badan Ibu dengan Stunting pada Balita Usia 24-59

Bulan di Desa Berasang Kecamatan Kisam Tinggi Kabupaten Oku

Selatan Tahun 2020

\begin{tabular}{|c|c|c|c|c|c|c|c|c|}
\hline \multirow{3}{*}{$\begin{array}{c}\text { Tinggi } \\
\text { Badan Ibu }\end{array}$} & \multicolumn{4}{|c|}{ Stunting } & \multirow{3}{*}{$\mathbf{N}$} & \multirow{3}{*}{$\%$} & \multirow{3}{*}{$p$ value } & \multirow{3}{*}{ OR } \\
\hline & \multicolumn{2}{|c|}{$\mathbf{Y a}$} & \multicolumn{2}{|c|}{ Tidak } & & & & \\
\hline & $\mathbf{n}$ & $\%$ & $\mathrm{n}$ & $\%$ & & & & \\
\hline Beresiko & 12 & 80 & 3 & 20 & 15 & 100 & & \\
\hline \multirow[t]{2}{*}{$\begin{array}{c}\begin{array}{c}\text { Tidak } \\
\text { beresiko }\end{array} \\
\end{array}$} & 11 & 44 & 14 & 56 & 25 & 100 & 0,026 & 1,146 \\
\hline & 23 & & 17 & & 40 & & & \\
\hline
\end{tabular}

Berdasarkan tabel 5 di atas diketahui dari 15 responden yang beresiko terdapat 12 responden $(80 \%)$ yang memiliki anak stunting, sedangkan dari 25 responden yang tidak beresiko terdapat 11 responden (44\%) yang memiliki anak stunting.

Dari hasil uji Chi-Square didapatkan nilai $P$ Value $=0,026<\alpha(0,05)$ hal ini menunjukkan bahwa ada hubungan yang bermakna antara tinggi badan ibu dengan stunting pada balita usia 24-59 bulan di
Desa Berasang Kecamatan Kisam Tinggi Kabupaten Oku Selatan Tahun 2020. Sedangkan nilai OR (odds ratio) didapatkan 1,146 hal ini menunjukkan bahwa ibu yang beresiko akan berpeluang untuk memiliki anak stunting sebesar 1,146 kali dibandingkan dengan ibu yang tidak beresiko.

Dengan demikian hipotesa awal yang menyatakan ada hubungan yang bermakna antara tinggi badan ibu dengan stunting pada balita usia 24-59 bulan di Desa Berasang Kecamatan Kisam Tinggi Kabupaten Oku Selatan Tahun 2020 terbukti secara statistik.

Hubungan Riwayat ASI Eksklusif Dengan Stunting pada Balita Usia 24-59 Bulan di Desa Berasang Kecamatan Kisam Tinggi Kabupaten Oku Selatan

Jumlah responden dalam penelitian ini adalah 40 orang. Analisis bivariat ini digunakan untuk mengetahui hubungan antara riwayat ASI Eksklusif dengan stunting pada balita usia 24-59 bulan di Desa Berasang Kecamatan Kisam Tinggi Kabupaten Oku Selatan yang dapat dilihat pada tabel dibawah ini.

Tabel 6 Hubungan Riwayat ASI Eksklusif Dengan Stunting pada Balita Usia 24-59 Bulan di Desa Berasang Kecamatan Kisam Tinggi Kabupaten Oku Selatan Tahun 2020

\begin{tabular}{|c|c|c|c|c|c|c|c|c|}
\hline \multirow{3}{*}{$\begin{array}{c}\text { Riwayat ASI } \\
\text { Eksklusif }\end{array}$} & \multicolumn{4}{|c|}{ Stunting } & \multirow{3}{*}{$\mathbf{N}$} & \multirow{3}{*}{$\%$} & \multirow{3}{*}{$p$ value } & \multirow{3}{*}{ OR } \\
\hline & \multicolumn{2}{|c|}{ Ya } & \multicolumn{2}{|c|}{ Tidak } & & & & \\
\hline & $\mathrm{n}$ & $\%$ & $\mathbf{n}$ & $\%$ & & & & \\
\hline Tidak & 17 & 84,2 & 3 & 15,8 & 19 & 100 & & \\
\hline \multirow[t]{2}{*}{ Ya } & 7 & 33,3 & 14 & 66,7 & 21 & 100 & 0,001 & 2,308 \\
\hline & 23 & & 17 & & 40 & & & \\
\hline
\end{tabular}

Berdasarkan tabel 6 di atas diketahui dari 19 responden yang Tidak diberikan ASI Eksklusif terdapat 16 responden (84,2\%) yang stunting 21 responden yang diberikan ASI Eksklusif terdapat 7 responden $(33,3 \%)$ yang stunting.

Dari hasil uji Chi-Square didapatkan nilai $P$ Value $=0,001<\alpha(0,05)$ hal ini menunjukkan bahwa ada hubungan yang bermakna antara Riwayat ASI Eksklusif dengan stunting pada balita usia 24-59 
bulan di Desa Berasang Kecamatan Kisam Tinggi Kabupaten Oku Selatan Tahun 2020. Sedangkan nilai OR (odds ratio) didapatkan 2,308 hal ini menunjukkan bahwa ibu yang tidak memberikan ASI Eksklusif akan berpeluang untuk memiliki anak stunting sebesar 2,308 kali dibandingkan dengan ibu yang memberikan ASI Eksklusif.

Dengan demikian hipotesa awal yang menyatakan ada hubungan yang bermakna antara Riwayat ASI Eksklusif dengan stunting pada balita usia 24-59 bulan di Desa Berasang Kecamatan Kisam Tinggi Kabupaten Oku Selatan Tahun 2020 terbukti secara statistik.

\section{Hubungan Riwayat BBLR Dengan Stunting pada Balita Usia 24-59 Bulan di Desa Berasang Kecamatan Kisam Tinggi Kabupaten Oku Selatan}

Jumlah responden dalam penelitian ini adalah 40 orang. Analisis bivariat ini digunakan untuk mengetahui hubungan antara riwayat BBLR dengan stunting pada balita usia 24-59 bulan di Desa Berasang Kecamatan Kisam Tinggi Kabupaten Oku Selatan tahun 2020 yang dapat dilihat pada tabel dibawah ini.

Tabel 7 Hubungan Riwayat BBLR Dengan

Stunting pada Balita Usia 24-59

Bulan di Desa Berasang Kecamatan

Kisam Tinggi Kabupaten Oku

Selatan Tahun 2020

\begin{tabular}{|c|c|c|c|c|c|c|c|c|}
\hline \multirow{3}{*}{$\begin{array}{c}\text { Riwayat } \\
\text { BBLR }\end{array}$} & \multicolumn{4}{|c|}{ Stunting } & \multirow{3}{*}{$\mathbf{N}$} & \multirow{3}{*}{$\%$} & \multirow{3}{*}{$p$ value } & \multirow{3}{*}{ OR } \\
\hline & \multicolumn{2}{|c|}{ Ya } & \multicolumn{2}{|c|}{$\begin{array}{c}\text { Tidak } \\
\end{array}$} & & & & \\
\hline & $\mathbf{n}$ & $\%$ & $\mathbf{n}$ & $\%$ & & & & \\
\hline Ya & 4 & 57,1 & 3 & 42,9 & 7 & 100 & & \\
\hline \multirow[t]{2}{*}{ Tidak } & 19 & 57,6 & 14 & 42,4 & 33 & 100 & 0,983 & 0,189 \\
\hline & 23 & & 17 & & 40 & & & \\
\hline
\end{tabular}

Berdasarkan tabel 7 di atas diketahui dari 7 responden yang BBLR terdapat 4 responden $(57,1 \%)$ yang stunting, sedangkan dari 33 responden yang Tidak BBLR terdapat 19 responden $(57,6 \%)$ yang stunting.

Dari hasil uji Chi-Square didapatkan nilai $P$ Value $=0,983>\alpha(0,05)$ hal ini menunjukkan bahwa tidak ada hubungan yang bermakna antara riwayat BBLR dengan stunting pada balita usia 24-59 bulan di Desa Berasang Kecamatan Kisam
Tinggi Kabupaten Oku Selatan tahun 2020. Sedangkan nilai OR (odds ratio) didapatkan 0,189 hal ini menunjukan bahwa balita memiliki riwayat BBLR berpeluang untuk mengalami stunting sebesar 0,189 kali dibandingkan balita yang tidak BBLR.

Dengan demikian hipotesa awal yang menyatakan ada hubungan yang bermakna antara antara riwayat BBLR dengan stunting pada balita usia 24-59 bulan di Desa Berasang Kecamatan Kisam Tinggi Kabupaten Oku Selatan tahun 2020 tidak terbukti secara statistik.

\section{Pembahasan \\ Stunting}

Stunting atau pendek merupakan kondisi gagal tumbuh pada bayi (0-11 bulan) dan anak balita (12-59 bulan) akibat dari kekurangan gizi kronis terutama dalam 1000 hari pertama kehidupan sehingga anak terlalu pendek untuk usianya. Kekurangan gizi terjadi sejak bayi dalam kandungan dan pada masa awal setelah bayi baru lahir, tetapi kondisi stunting baru nampak setelah berusia 2 tahun. Balita dikatakan pendek jika nilai zscore-nya panjang badan menurut umur $(\mathrm{PB} / \mathrm{U})$ atau tinggi badan menurut umur (TB/U) kurang dari -2D/standar deviasi (stunted) dan kurang dari -3SD (severely stunted). Balita stunted akan memiliki tingkat kecerdasan tidak maksimal, menjadi lebih rentan terhadap penyakit dan masa depan dapat berisiko menurunnya tingkat produktivitas. Pada akhirnya, secara luas, stunting akan dapat menghambat pertumbuhan ekonomi dan meningkatkan kemiskinan (Ramayulis dkk, 2018).

Berdasarkan hasil analisis univariat diketahui distribusi frekuensi responden sebagian besar mengalami stunting $(57,5 \%)$.

Hasil penelitian ini sejalan dengan penelitian Rohmatun (2014), yang berjudul hubungan tingkat pendidikan ibu dan pemberian ASI Eksklusif dengan kejadian 
stunting pada balita di Desa Sidowarno Kecamatan Wonosari Kabupaten Klaten. Hasil penelitian didapat bahwa responden yang stunting sebanyak 34 responden $(53,1 \%)$ dan responden yang tidak stunting sebanyak 30 responden $(46,9 \%)$.

Hal ini sejalan dengan penelitian Aini, Nugraheni, dan Pradigdo (2018) yang berjudul faktor yang mempengaruhi stunting pada balita usia 24-59 bulan di puskesmas Cepu Kabupaten Blora. Hasil penelitian didapat bahwa pada kelompok usia 24-35 bulan persentasenya lebih banyak terdapat pada kelompok balita stunting $(71,1 \%)$ dibandingkan dengan kelompok balita normal $(60,5 \%)$. Lain halnya pada kelompok balita usia 36-59 bulan, persentasenya lebih banyak terdapat pada kelompok balita normal $(39,5 \%)$ dibandingkan dengan kelompok balita stunting $(28,9 \%)$.

Menurut Helmyati dkk (2017) Stunting merupakan keadaan tubuh yang sangat pendek, yaitu di bawah -2 SD berdasarkan indikator $\mathrm{TB} / \mathrm{U}$, berdasarkan usia dan jenis kelamin pada stantar pertumbuhan. Stunting ditentukan dengan pengukuran panjang atau tinggi badan yang dibandingkan dengan usianya

Hal ini sejalan dengan pernyataan Yuliana, Hakim (2019) Faktor gizi ibu sebelum dan selama kehamilan merupakan penyebab tidak langsung yang memberikan kontribusi terhadap pertumbuhan dan perkembangan janin. Ibu hamil dengan gizi kurang akan menyebabkan janin mengalami interauterine growth retardation (IUGR), sehingga bayi akan lahir dengan kurang gizi, dan mengalami gangguan pertumbuhan dan perkembangan. Anakanak yang mengalami hambatan dalam pertumbuhan disebabkan kurangnya asupan makanan dan penyakit infeksi yang berulang, maka keadaan ini sangat berpeluang terjadinya stunting.

Berdasarkan hasil penelitian dan pembahasan diatas peneliti berasumsi bahwa masih banyak ibu yang memiliki anak stunting (57,5\%). Hal ini disebabkan karena masih banyak ibu yang kurang memahami tentang pentingnya asupan gizi pada masa kehamilan, pada masa awal setelah bayi baru lahir, dan pada 1000 hari pertama kehidupan. Hal inilah yang menyebabkan masih tingginya anggka kejadian stunting.

\section{Hubungan Tinggi Badan Ibu Dengan Stunting}

Berdasarkan hasil analisis univariat diketahui distribusi frekuensi responden sebagian besar tidak beresiko $(62,5 \%)$. Berdasarkan tabel 5 di atas diketah uidari 15 responden yang beresiko terdapat 12 responden $(80 \%)$ yang memiliki anak stunting, sedangkan dari 25 responden yang tidak beresiko terdapat 11 responden (44\%) yang memiliki anak stunting. Dari hasil uji Chi-Square didapatkan nilai $P$ Value $=0,026<\alpha(0,05)$ hal ini menunjukkan bahwa ada hubungan yang bermakna antara tinggi badan ibu dengan stunting pada balita usia 24-59 bulan di Desa Berasang Kecamatan Kisam Tinggi Kabupaten Oku Selatan Tahun 2020. Sedangkan nilai OR (odds ratio) didapatkan 1,146 hal ini menunjukkan bahwa ibu yang beresiko akan berpeluang untuk memiliki anak stunting sebesar 1,146 kali dibandingkan dengan ibu yang tidak beresiko.

Dengan demikian hipotesa awal yang menyatakan ada hubungan yang bermakna antara tinggi badan ibu dengan stunting pada balita usia 24-59 bulan di Desa Berasang Kecamatan Kisam Tinggi Kabupaten Oku Selatan Tahun 2020 terbukti secara statistik.

Hasil penelitian ini sejalan dengan penelitian Amalia (2017), yang berjudul faktor-faktor yang berhubungan dengan stunting pada balita usia $24-59$ bulan di wilayah kerja Puskesmas Wonosari I. Hasil penelitian didapat bahwa tinggi badan ibu dengan kategori pendek sebanyak 26 orang $(68,4 \%)$ ibu memiliki 
anak stunting. Hasil uji statistik menggunakan nilai p $0,000 \quad(\mathrm{p}<0,05)$ sehingga dapat dinyatakan bahwa ada hubungan antara tinggi badan ibu dengan stunting pada balita usia 24-59 bulan di wilayah kerja Puskesmas Wonosari I.

Hasil penelitian ini juga sejalan dengan penelitian Novelinda (2018), yang berjudul hubungan tinggi badan orang tua dengan kejadian stunting pada anak usia 24-59 bulan di Kecamatan Ratahan Kabupaten Minahasa Tenggara. Berdasarkan uji chisquare yang telah dilakukan didapatkan dalam penelitian ini $p$ value $=0,000$ maka dari itu, didapatkan nilai $\mathrm{p}<0,05$ yang berarti Ho ditolak, sehingga dapat disimpulkan ada hubungan antara tinggi badan ibu dengan kejadian stunting pada balita.

Hal ini serupa dengan pernyataan Amin dalam Ratu, Punuh dan Malonda (2018) Faktor tinggi badan ibu merupakan faktor risiko kejadian stunting pada balita. Tinggi badan ibu dikelompokan menjadi ibu pendek $(<150 \mathrm{~cm})$ dan ibu normal $(\geq 150 \mathrm{~cm})$, ibu yang pendek memiliki kemungkinan melahirkan bayi yang pendek pula, hasil penelitian menunjukan bahwa ibu dengan tinggi badan $<150 \mathrm{~cm}$ memiliki risiko lebih tinggi melahirkan anak yang stunting.

Menurut Rahayu dalam Ratu, Punuh dan Malonda (2018) Anak yang dilahirkan dari ibu yang pendek berisiko menjadi stunting, karena akibat kondisi fisik memiliki pewaris dalam struktur gen yang dapat membawa sifat pendek sehingga memperoleh peluang anak untuk mewarisi gen sehingga tumbuh menjadi stunting.

Berdasarkan hasil penelitian dan pembahasan diatas peneliti berasumsi bahwa tinggi badan ibu berhubungan dengan stunting. Ibu yang memiliki tinggi badan yang beresiko memiliki resiko lebih tinggi untuk melahirkan anak yang stunting dibandingkan ibu yang memiliko tinggi badan tidak beresiko.

\section{Hubungan Riwayat ASI Eksklusif dengan Stunting}

Berdasarkan hasil analisis univariat diketahui distribusi frekuensi responden sebagian besar diberikan ASI Eksklusif (52,5\%). Berdasarkan tabel 6 di atas diketahui dari 19 responden yang Tidak diberikan ASI Eksklusif terdapat 16 responden $(84,2 \%)$ yang stunting 21 responden yang diberikan ASI Eksklusif terdapat 7 responden $(33,3 \%)$ yang stunting. Dari hasil uji Chi-Square didapatkan nilai $P$ Value $=0,001<\alpha$ $(0,05)$ hal ini menunjukkan bahwa ada hubungan yang bermakna antara Riwayat ASI Eksklusif dengan stunting pada balita usia 24-59 bulan di Desa Berasang Kecamatan Kisam Tinggi Kabupaten Oku Selatan Tahun 2020. Sedangkan nilai OR (odds ratio) didapatkan 2,308 hal ini menunjukkan bahwa ibu yang tidak memberikan ASI Eksklusif akan berpeluang untuk memiliki anak stunting sebesar 2,308 kali dibandingkan dengan ibu yang memberikan ASI Eksklusif. Dengan demikian hipotesa awal yang menyatakan ada hubungan yang bermakna antara Riwayat ASI Eksklusif dengan stunting pada balita usia 24-59 bulan di Desa Berasang Kecamatan Kisam Tinggi Kabupaten Oku Selatan Tahun 2020 terbukti secara statistik.

Hal ini sejalan dengan penelitian Sri (2016), yang berjudul hubungan pemberian ASI Eksklusif dengan kejadian stunting pada anak usia 2-3 tahun di desa Karangrejek Wonosari Gunungkidul. Hasil penelitian menunjukkan bahwa sebagian besar responden yang dalam kategori sangat pendektidak mendapatkan ASI Eksklusif yaitu 10 responden $(7,7 \%)$. Responden dalam kategori pendek sebagian besar mendapatkan ASI Eksklusif yaitu 18 responden $(13,8 \%)$. Responden yang dalam kategori normal sebagian besar mendapatkan ASI Eksklusif yaitu 92 responden $(70,8 \%)$. Hubungan pemberian ASI eksklusif dengan kejadian stunting 
pada balita 2-3 tahun. Dimana diperoleh $p$ value $=0,000(0,000<0,05)$. Maka disimpulkan bahwa terdapat hubungan pemberian ASI eksklusif dengan kejadian stunting pada balita 2-3 tahun.

Hasil penelitian ini juga sejalan dengan penelitian Intan (2017), yang berjudul ASI Eksklusif, panjang badan lahir, berat badan lahir rendah sebagai faktor risiko terjadinya stunting pada anak usia 6-24 bulan di Puskesmas Lendah II Kulon Progo. Hasil uji statistik chi square diperoleh nilai $\mathrm{p}=0,000(\mathrm{p}<0,05)$ dengan demikian dapat disimpulkan bahwa terdapat hubungan yang bermakna antara riwayat pemberian ASI Eksklusif dengan risiko kejadian stunting pada anak di wilayah Puskesmas Lendah II Kabupaten Kulon Progo.

Hal serupa diungkapkan Ariati (2019), ASI merupakan nutrisi utama yang dibutuhkan oleh bayi karena merupakan sumber protein yang berkualitas dan mengandung zat-zat yang berguna untuk imunitas tubuh. Kurangnya pemberian ASI dan pemberian MPASI dini dapat meningkatkan risiko terjadinya stunting pada awal masa kehidupan.

Menurut Fikadu, et al dalam Ni'mah dan Nadhiroh (2015), Faktor lain yang berhubungan dengan stunting adalah asupan ASI Eksklusif pada balita. Penelitian di Ethiopia Selatan membuktikan bahwa balita yang tidak mendapatkan ASI Eksklusif selama enam bulan berisiko tinggi mengalami stunting.

Berdasarkan hasil penelitian dan pembahasan diatas peneliti berasumsi bahwa riwayat ASI Eksklusif berhubungan dengan stunting. Balita yang tidak diberi ASI Eksklusif serta diberikan MPASI dini beresiko tinggi untuk mengalami stunting dibandingkan balita yang diberi ASI Eksklusif .

\section{Hubungan Riwayat BBLR dengan Stunting}

Berdasarkan hasil analisis univariat diketahui Dari tabel 4 diatas dapat dilihat bahwa distribusi frekuensi responden sebagian besar tidak memiliki riwayat BBLR (82,5\%). Berdasarkan tabel 7 di atas diketahui dari 7 responden yang BBLR terdapat 4 responden $(57,1 \%)$ yang stunting, sedangkan dari 33 responden yang Tidak BBLR terdapat 19 responden $(57,6 \%)$ yang stunting. Dari hasil uji ChiSquare didapatkan nilai $P$ Value $=0,983>$ $\alpha(0,05)$ hal ini menunjukkan bahwa tidak ada hubungan yang bermakna antara riwayat BBLR dengan stunting pada balita usia 24-59 bulan di Desa Berasang Kecamatan Kisam Tinggi Kabupaten Oku Selatan tahun 2020. Sedangkan nilai OR (odds ratio) didapatkan 0,189 hal ini menunjukan bahwa balita memiliki riwayat BBLR berpeluang untuk mengalami stunting sebesar 0,189 kali dibandingkan balita yang tidak BBLR. Dengan demikian hipotesa awal yang menyatakan ada hubungan yang bermakna antara antara riwayat BBLR dengan stunting pada balita usia $24-59$ bulan di Desa Berasang Kecamatan Kisam Tinggi Kabupaten Oku Selatan tahun 2020 tidak terbukti secara statistik.

Hasil penelitian ini berbeda dengan penelitian Amalia (2017), yang berjudul faktor-faktor yang berhubungan dengan stunting pada balita usia 24-59 bulan di wilayah kerja Puskesmas Wonosari I. Hasil penelitian didapat bahwa balita dengan riwayat BBLR dan mengalami stunting sebanyak 10 orang $(62,5 \%)$ sementara balita yang tidak memiliki riwayat BBLR dan mengalami stunting sebanyak (32,9\%). Hasil uji statistik menggunakan chi-square didapatkan nilai p $0,045 \quad(p<0,05)$ sehingga dinyatakan bahwa ada hubungan antara BBLR dengan stunting pada balita usia 24-59 bulan di wilayah kerja Puskesmas Wonosari I.

Berdasarkan hasil uji Fisher Exact dengan tingkat kepercayaan $95 \%$ didapat bahwa ada hubungan yang bermakna antara riwayat BBRL dengan kejadian stunting pada balita. Dampak dari bayi 
yang memiliki berat badan lahir rendah akan berlangsung antara generasi yang satu ke generasi yang selanjutnya. Anak yang BBRL kedepannya akan memiliki ukuran antropometri yang kurang dimasa dewasa. Bagi perempuan yang lahir dengan berat rendah memiliki risiko besar untuk menjadi ibu yang stunting sehingga akan cenderung melahirkan bayi dengan berat lahir rendah (Wulandari dkk, 2018)

Hasil penelitian ini sejalan dengan penelitian Ni'mah dan Nadhiroh (2015) yang berjudul faktor yang berhubungan dengan kejadian stunting pada balita. Hasil penelitian didapat bahwa balita yang BBLR dan mengalami stunting sebanyak 4 orang $11,8 \%$ ) sementara balita yang tidak BBLR yang dan mengalami stunting sebanyak 30 orang $(88,2 \%)$. Hasil uji Fisher Exact dengan tinggkat kepercayaan 95\% didapatkan bahwa tidak ada hubungan yang bermakna antara BBLR dengan kejadian stunting pada balita $(\mathrm{p}=1,000)$.

Menurut penelitian Darwin (2014), yang bejudul Berat badan lahir rendah (BBLR) dengan kejadian stunting pada anak usia 6-24 bulan. Hasil analisis menunjukkan nilai $\mathrm{OR}=5,60 \quad(95 \% \mathrm{CI}$ : 2,27-15,70), artinya pada tingkat kepercayaan $95 \%$ dapat disimpulkan bahwa anak yang lahir dengan BBLR mempunyai risiko 5,6 kali lebih besar untuk menjadi stunting dibandingkan dengan anak yang lahir dengan berat badan normal.

Anak yang dilahirkan dengan berat badan lahir rendah berisiko mengalami stunting karena pertumbuhan dan perkembangan anak terhambat (Aisyah et al dalam Wulandari dkk, 2018).

Berdasarkan hasil penelitian dan pembahasan peneliti berasumsi bahwa riwayat BBLR tidak berhubungan dengan stunting. Hal ini dapat disebabkan oleh banyak faktor yang lebih besar pengaruhnya dengan kejadian stunting pada balita seperti ketidakcukupan gizi dan riwayat ASI Eksklusif.

\section{KESIMPULAN}

1. Distribusi frekuensi sebagian besar responden mengalami stunting $(57,5 \%)$.

2. Distribusi frekuensi sebagian besar tidak beresiko $(62,5 \%)$.

3. Distribusi frekuensi sebagian besar diberikan ASI Eksklusif (52,5\%).

4. Distribusi frekuensi sebagian besar tidak memiliki riwayat BBLR $(82,5 \%)$.

5. Ada hubungan yang bermakna antara tinggi badan ibu dengan stunting pada balita usia 24-59 bulan di Desa Berasang Kecamatan Kisam Tinggi Kabupaten Oku Selatan Tahun 2020 dengan nilai $P$ Value $=0,026<\alpha$ $(0,05)$.

6. Ada hubungan yang bermakna antara riwayat ASI Eksklusif dengan stunting pada balita usia 24-59 bulan di Desa Berasang Kecamatan Kisam Tinggi Kabupaten Oku Selatan Tahun 2020 dengan nilai $P$ Value $=0,001<\alpha$ $(0,05)$.

7. Tidak ada hubungan yang bermakna antara riwayat BBLR dengan stunting pada balita usia 24-59 bulan di Desa Berasang Kecamatan Kisam Tinggi Kabupaten Oku Selatan Tahun 2020 dengan nilai $P$ Value $=0,983>\alpha$ $(0,05)$.

\section{SARAN \\ Bagi Desa Berasang Kecamatan Kisam Tinggi Kabupaten Oku Selatan}

Diharapkan tenaga kesehatan khususnya bidan yang ada di Desa Berasang Kecamatan Kisam Tinggi Kabupaten Oku Selatan agar lebih meningkatkan dalam pemberian informasi kepada masyarakat melalui pendekatan persuasif dengan menjelaskan kepada masyarakat bahwa stunting harus atau dapat dicegah mulai dari memenuhi gizi 
ibu hamil, gizi bayi baru lahir dan 1000 hari pertama kehidupan.

\section{Bagi Peneliti Selanjutnya}

Peneliti selanjutnya diharapkan dapat melakukan penelitian tentang stunting dengan menggunakan metode penelitian yang berbeda dan mencari variabel lain yang lebih bervariasi yang ada kaitannya dengan stunting pada balita usia 24-59 bulan serta dengan mengambil sampel yang lebih banyak lagi sehingga penelitian tentang stunting dapat terus dikembangkan.

\section{DAFTAR PUSTAKA}

[1] Rahmayulis, Rita dkk. 2018. Stop Stunting dengan Konseking Gizi. Jakarta : Penebar Swadaya Grup

[2] Sandjaja dan Atmarita. 2009. Kamus Gizi : Pelengkap Kesehatan Keluarga. Jakarta : Kompas Media Nusantara

[3] Suhaimi, Ahmad. 2019. Pangan, Gizi, dan Kesehatan. Yogyakarta : Deepublish

[4] Puskesmas Kisam Tinggi. 2019. Stunting di Wilayah Kerja Puskesmas Kisam Tinggi.

[5] Rohmatun, Nining Yuliani. 2014. Hubungan Tingkat Pendidikan Pemberian ASI Eksklusif dengan Kejadian Stunting pada Balita di Desa Sidowarno Kecamatan Wonosari Kabupaten Klaten

[6] Aini, Sri Achadi Nugraheni dan Siti Fatimah Pradigdo. 2018. Faktor yang Mempengaruhi Stunting pada Balita Usia 24-59 Bulan di Puskesmas Cepu Kabupaten Blora. Kesehatan Masyarakat. Volume 6, Nomor 5, Oktober 2018 (ISSN : 2356-3346)
[7] Helmyati, Siti dkk. 2017. Fortifikasi Pangan Berbasis Sumberdaya Nusantara : Upaya Mengatasi Masalah Defisiensi Zat Gizi Mikrodi Indonesia. Yogyakarta: Gadjah Mada University Press

[8] Yuliana, Wahida dan Bawon Nul Hakim. 2019. Darurat Stunting dengan Melibatkan Keluarga. Selawesi Selatan : Yayasan Ahmar Cendika Indonesia

[9] Rochmah, Amalia Miftakul dan Enny Fitriahadi. 2017. Faktor-Faktor yang Berhubungan dengan Stunting pada Balita Usia 24-59 Bulan di Wilayah Kerja Puskesmas Wonosari I.

[10] Ratu, Novelinda Ch. dkk. 2018. Hubungan Tinggi Badan Orang Tua dengan Kejadian Stunting pada anak Usia 24-59 Bulan di Kecamatan Ratahan Kabupaten Minahasa Tenggara. KESMAS. 7 Nomor 4

[11] Indrawati, Sri dan Warsiti. 2016. Hubungan Pemberian ASI Eksklusif dengan Kejadian Stunting pada Anak Usia 2-3 Tahun di Desa Karangrejek Wonosari Gunungkidul

[12] Kusumawardhani, Intan dkk. 2017. ASI Eksklusif, Panjang Badan Lahir, Berat Badan Lahir Rendah Sebagai Faktor Risiko Terjadinya Stunting pada Anak Usia 6-24 Bulan di Puskesmas Lendah II Kulon Progo

[13] Ariati, Linda Ika Puspita. 2019. Faktor-Faktor Resiko Penyebab Terjadinya Stunting Pada Balita Usia 23-59 bulan. Oksitosin, Kebidanan. VI, No. 1, Februari 2019 : 28-37

[14] Ni'mah, Khoirun dan Siti Rahayu Nadhiroh. 2015. Faktor Yang Berhubungan dengan Kejadian Stunting pada Balita. Media Gizi 
Indonesia. 10, No. 1 Januari-Juni $2015: 13-19$

[15] Nasution, Darwin dkk. 2014. Berat Badan Lahir Rendah (BBLR) dengan Kejadian Stunting pada Anak Usia 624 bulan.Jurnal Gizi Klinik Indonesia. 11, No. 01 Juli $2014: 31-37$

[16] Wulandari, Resti dkk. 2018. Hubungan Antara Riwayat BBLR, Riwayat ASI Eksklusif dan Panjang Badan Saat Lahir Terhadap Kejadian Stunting pada Anak Usia 7-23 Bulan di Puskesmas panongan Kabupaten Tangerang 